\title{
GAMBARAN KONDISI KESEPIAN MAHASISWA YANG HANYA MENGAMBIL MATA KULIAH SKRIPSI PROGRAM PENDIDIKAN S-1 UNIVERSITAS PADJADJARAN
}

\author{
Ismi Putri Herianda, Esti Wungu, dan Rintana Dewi \\ Fakultas Psikologi, Universitas Padjadjaran \\ Jalan Raya Bandung-Sumedang KM 21 Jatinangor, Sumedang, 45363 \\ Email: ismi.herianda@gmail.com
}

\begin{abstract}
ABSTRAK
Kesepian adalah kondisi yang tidak menyenangkan, subjektif, dan terjadi saat interaksi jika adanya kebutuhan dalam hubungan sosial yang tidak terpenuhi. Kesepian terbagi ke dalam dua jenis, yaitu kesepian sosial (terjadi karena hubungan pertemanan) dan kesepian emosional (terjadi karena hubungan keluarga dan hubungan percintaan). Mahasiswa Universitas Padjadjaran yang hanya mengambil mata kuliah skripsi mengalami perubahan interaksi sosial, seperti jarang bertemu dan perbedaan topik pembicaraan dengan teman yang sudah lulus maupun belum lulus, merasa tertekan oleh keluarga, dan perubahan dalam hubungan percintaan. Oleh karena itu, peneliti tertarik untuk melihat gambaran empiris mengenai kondisi kesepian yang dilihat dari kondisi kesepian sosial dan kondisi kesepian emosional pada mahasiswa tersebut. Penelitian dilakukan terhadap 330 mahasiswa Universitas Padjadjaran dengan karakteristik angkatan 2013-2015 yang hanya mengambil mata kuliah skripsi menggunakan teknik proporsional stratified random sampling. Peneliti menggunakan rancangan noneksperimental dengan metode penelitian deskriptif dan pendekatan kuantitatif dengan menyebarkan kuesioner SELSA (Social Loneliness Scale For Adults) secara daring. Hasil penelitian memperlihatkan mayoritas mahasiswa memiliki kondisi kesepian $(n=272)$, kesepian sosial $(n=271)$, dan kesepian emosional $(n=233)$ pada tingkat yang rendah. Hal ini disebabkan oleh kesendirian dan sudah dapat mengatasi kesepian yang dirasakan saat sedang sendirian.
\end{abstract}

Kata kunci: kesepian; kesepian sosial; kesepian emosional; skripsi; Universitas Padjadjaran

\section{DESCRIPTION OF THE CONDITION OF LONELINESS IN BACHELOR PROGRAM STUDENTS TAKING ONLY THESIS COURSES IN UNIVERSITAS PADJADJARAN}

\begin{abstract}
Loneliness is an unpleasant condition, subjective, and occurs when interactions in individual social relationships declined, or there are needs in social relationships that are not filled. Loneliness is divided into two types, social loneliness that occurs due to friendship relationships and emotional loneliness that occurs due to family relationships and romantic relationships. Students who only took thesis courses can have experienced changes in social interactions, such as rarely met friends who have graduated or not graduated, differences in the topic of conversation with friends, feel pressured by the family because they had not graduated, and changed in love relationships. Therefore, the researchers were interested to see a picture of the condition of loneliness as seen from the condition of social loneliness and emotional loneliness in students who only take thesis subjects. The study was conducted on 330 Universitas Padjadjaran students with the characteristics of the class of 2013-2015 who only took thesis courses and this research used proportional stratified random sampling techniques. The researchers used non-experimental designs with descriptive research methods and quantitative approaches by distributed SELSA questionnaires online. The results showed the majority of students had a low level of lonely conditions $(n=272)$, low level at social loneliness $(n=271)$, and low level at emotional loneliness $(n=233)$. That was because they feel lonely when they were alone, and could overcome the problem of loneliness by done activities that could be enjoyed by themself.
\end{abstract}

Keywords: loneliness; social loneliness; emotional loneliness; thesis; Universitas Padjadjaran 


\section{PENDAHULUAN}

Perlman dan Peplau (1984) mendefinisikan kesepian sebagai kondisi yang tidak menyenangkan dan bersifat subjektif, terjadi ketika interaksi dalam hubungan sosial (pertemanan; keluarga; percintaan) individu mengalami penurunan baik secara kuantitas maupun kualitas. Menurut Weiss (1974), kesepian dapat terjadi ketika adanya kebutuhan dalam hubungan sosial yang belum terpenuhi dan terdapat dua jenis kesepian. Adapun dua jenis kesepian menurut Weiss (1974) kesepian yang terjadi ketika individu tidak memenuhi kebutuhan akan social integration (kebutuhan untuk bertukar informasi dan pengalaman dengan orang lain) terutama dalam hubungan pertemanan sehingga akan menyebabkan kesepian sosial (social loneliness) dan kesepian yang terjadi ketika individu tidak memenuhi kebutuhan akan guidance (rasa percaya dan sosok yang dapat diandalkan) dalam hubungan keluarga dan attachment (kebutuhan akan kasih sayang atau kedekatan) dalam hubungan percintaan dan jika salah satu atau keduanya tidak terpenuhi dapat menyebabkan kesepian emosional (emotional loneliness). Menurut Perlman dan Peplau (1984) terdapat tiga faktor yang membuat individu belum dapat memenuhi kebutuhan hubungan sosialnyadan bisa merasakan kesepian. Faktor predisposing (faktor kepribadian, demografis, akses dan kemampuan dalam hubungan sosial, kesamaan individu dengan lingkungan sosialnya). Faktor precipitate event (kondisi atau situasi yang dianggap dapat memacu meningkatkan kesepian, seperti putus dalam hubungan percintaan atau pergi merantau untuk berkuliah, dsb.). Faktor kognitif (individu mengetahui apa yang menyebabkan mereka kesepian atau merasa bahwa dirinya tidak memiliki control terhadap lingkungan sosialnya).

Berdasarkan konsep yang telah dipaparkan sebelumnya kesepian dapat terjadi pada siapa saja, tidak memandang jenis kelamin maupun usia. Namun pada tahun 2018, berdasarkan hasil survei yang dilakukan oleh Australian Psychological Society di Inggris dan Australia, menunjukkan bahwa usia 18-25 tahun adalah usia yang paling sering mengalami kondisi kesepian. Menurut Qualter, Lee dan Goldstein (2015) hal ini dapat disebabkan pada rentang usia tersebut disebabkan oleh perubahan kuantitas maupun kualitas hubungan yang terjadi, seperti penurunan jumlah teman dekat, tidak diakui sebagai teman atau sahabat maupun sebagai pasangan. Jika melihat dari teori perkembangan, usia 18 s.d. 25 tahun merupakan rentang usia yang termasuk dalam tahap emerging adulthood. Menurut Arnett (2014), pada tahap ini, individu cenderung melakukan eksplorasi diri hingga pindah dan tinggal jauh dari orang tua, adanya ketidakstabilan dalam hubungan sosial, dan harus berfokus dengan dirinya sendiri untuk mencapai tujuan hidupnya.

Rentang usia 18 s.d 25 tahun di Indonesia, merupakan usia individu yang sedang menempuh pendidikan di perguruan tinggi sebagai mahasiswa, terutama jenjang pendidikan sarjana. Di Universitas Padjadjaran pada akhir studi, mahasiswa diwajibkan untuk melakukan penyusunan dan penulisan skripsi sebagaimana yang telah ditentukan oleh fakultasnya masing-masing. Beberapa fakultas menetapkan skripsi dapat dimulai sejak semester tujuh dengan syarat telah memenuhi SKS (Satuan Kredit Semester), meskipun beberapa fakultas yang menetapkan skripsi dapat dimulai semester delapan.

Pada November 2019, berdasarkan data Direktorat Pendidikan dan Kemahasiswaan (DIRDIKMAWA), tercatat 2.884 mahasiswa Universitas Padjadjaran angkatan 2013 sampai 2015 yang belum lulus dan mayoritas mahasiswa kemungkinan hanya mengambil mata kuliah skripsi. Mahasiswa yang hanya mengambil mata kuliah skripsi dapat merasakan perubahan intensitas dalam hubungan sosial, seperti jarang bertemu dengan teman-teman karena perpisahan jarak atau perbedaan situasi serta mulai adanya perbedaan diantara mahasiswa yang hanya mengambil mata kuliah skripsi, seperti perbedaan dosen pembimbing, jadwal bimbingan, lokasi penelitian, hambatan pengerjaan skripsi, dan tidak ada lagi mata kuliah yang diambil bersama dengan teman-teman di kelas sehingga menyebabkan topik pembicaraan menjadi lebih sedikit. Peneliti melakukan wawancara pada tujuh orang mahasiswa Universitas Padjadjaran yang hanya mengambil mata kuliah skripsi untuk lebih menggali fenomena kesepian yang dilihat dari hubungan sosial (hubungan pertemanan, hubungan keluarga dan hubungan percintaan). Berdasarkan hasil wawancara tersebut, empat dari tujuh mahasiswa merasakan bahwa interaksi dengan temanteman yang telah lulus maupun belum lulus menurun. Pada hubungan keluarga, enam dari tujuh mahasiswa merasa tertekan oleh lingkungan keluarga, sedangkan pada hubungan percintaan tiga dari tujuh mahasiswa merasakan penurunan dalam hubungan percintaannya. Jika melihat sumber hubungan yang menyebabkan kesepian, enam dari tujuh mahasiswa cenderung merasakan kesepian karena hubungan sosial. Kemudian, dua mahasiswa merasakan kesepian karena hubungan pertemanan, satu mahasiswa merasakan kesepian karena hubungan keluarga, satu 
mahasiswa merasakan kesepian karena hubungan percintaan, serta dua mahasiswa lainnya merasakan kesepian karena hubungan keluarga dan hubungan percintaan.

Selain penyebab kesepian, peneliti juga menanyakan dampak dari kesepian yang dirasakan oleh tujuh mahasiswa tersebut. Hasilnya empat mahasiswa merasakan dampak negatif dari kesepian, seperti menjadi malas mengerjakan skripsi, menangis, mood berubah menjadi jelek, stres, merasakan gelisah, dan merasa bingung apa yang harus dilakukan. Namun, tiga diantaranya merasakan skripsi memberikan dampak positif, seperti menjadi rajin untuk membereskan kosan, merencanakan kegiatan untuk memperlancar pengerjaan skripsinya, mencari teman untuk berinteraksi atau melakukan kegiatan yang disukai.

Berdasarkan beberapa penelitian yang telah dilakukan sebelumnya, diketahui bahwa kesepian lebih banyak memicu dampak negatif, seperti stres, depresi, bahkan gagasan bunuh diri pada individu (Chang, dkk. 2017; Matthews, 2016; Pervin dan Ferdowshi, 2016). Menurut Bek (2017) kesepian yang dikarenakan hubungan pertemanan dapat mempengaruhi performa akademik mahasiswa. Oleh karena itu, berdasarkan pemaparan data awal dan penelitian yang telah dilakukan, peneliti ingin melihat bagaimana gambaran kesepian pada mahasiswa yang hanya mengambil mata kuliah skripsi (tanpa mengambil mata kuliah mengulang atau pilihan), dilihat dari aspek kesepian sosial dan kesepian emosional.

\section{METODE}

Penelitian ini menggunakan rancangan penelitian non-eksperimental dengan menggunakan metode penelitian deskriptif dan pendekatan kuantitatif, untuk menyediakan, menjelaskan secara numerik dan membuktikan gambaran dari fenomena tertentu (Christensen, 2014).

Populasi pada penelitian ini adalah sebanyak 2,884 Mahasiswa Universitas Padjadjaran dari angkatan 2013, 2014 dan 2015, yang didapatkan setelah wisuda gelombang satu tahun ajaran 2019/2020. Kriteria sampel dalam penelitian ini adalah mahasiswa Universitas Padjadjaran angkatan 2013, 2014, dan 2015 yang hanya mengambil mata kuliah skripsi. Peneliti menggunakan teknik proporsional stratified random sampling, yaitu jumlah orang yang terpilih dari kelompok cukup proporsional untuk populasi dan setiap individu memiliki kesempatan yang sama untuk termasuk dalam sampel akhir. Berikut merupakan langkah penentuan jumlah sampling pada mahasiswa Universitas Padjadjaran menggunakan rumus dari Morgan dan Krejcie (1970):

$$
s=\frac{X^{2} \cdot N \cdot P(1-P)}{\left(d^{2}(N-1)+X^{2} P(1-P)\right)}
$$

$$
\begin{array}{ll}
\mathrm{X}^{2} & \text { : nilai dari tabel chi-square }(3.841) \\
\mathrm{N} & \text { : Jumlah Populasi } \\
\mathrm{P} & \text { : Porsi populasi, diasumsikan } .50 \\
\mathrm{~d} & \text { : derajat akurasi } .05
\end{array}
$$

Berdasarkan perhitungan dengan sampel dengan rumus Morgan dan Krejcie (1970), didapatkan sampel minimal yaitu sebanyak 303 mahasiswa. Kemudian untuk mendapatkan jumlah pada setiap rumpun pendidikan, peneliti menggunakan proporsional-stratified, dengan menggunakan rumus proporsional sebagai berikut (dalam Hasan, 2001):

$$
\frac{\text { Jumlah Sampel }}{\text { Jumlah Populasi }} \times \text { Jumlah Populasi Kelompok }
$$

Berdasarkan perhitungan tersebut didapatkan sampel tiap rumpun pendidikan di Universitas Padjadjaran, yaitu rumpun argokompleks sebanyak 74 mahasiswa rumpun kesehatan sebanyak 22 mahasiswa, rumpun saintek sebanyak 29 mahasiswa, dan rumpun sosiohumaniora sebanyak 179 mahasiswa.

Alat ukur yang digunakan untuk mengukur tingkat kesepian adalah Social-Emotional Loneliness Scale for Adults (SELSA) yang dikembangkan oleh Enrico DiTomasso dan Barry Spinner pada tahun 1993. Alat ukur 
ini menggunakan pendekatan kesepian yang diungkapkan oleh Weiss dan telah diterjemahkan ke dalam Bahasa Indonesia oleh Kesya Andini (2009), mahasiswa Universitas Indonesia. Alat ukur SELSA memiliki dua dimensi yaitu dimensi kesepian sosial (Social Loneliness) dengan sub-dimensi Social-Relationship Subscale dan dimensi kesepian emosional (Emotional Loneliness) dengan sub-dimensi Family-Relationship Subscale dan Romantic-Relationship Subscale. Berdasarkan pengujian reliabilitas dari penelitian sebelumnya, masingmasing dimensi dari alat ukur SELSA memiliki reliabilitas dalam rentang .89-.93 (Muhammadin, 2015) dan berdasarkan pengujian validitas oleh peneliti menggunakan lisrel, didapatkan nilai p-value dalam rentang .00066-.076 yang menunjukkan bahwa SELSA berada pada nilai goodfit.

Peneliti menggunakan kuisioner online (google form) yang disebarkan melalui social media. Terdapat beberapa bagian pada google form tersebut, yaitu pengisian data diri, setelah itu alat ukur SELSA dibagi ke dalam 3 section berdasarkan sub-dimensi alat ukurnya. Responden diminta untuk memberikan tanggapan terhadap pernyataan-pernyataan pada item-item alat ukur SELSA, dengan skala likert 1-7 (1 : Sangat Tidak Setuju ; 2: Tidak Setuju ; 3 : Agak Tidak Setuju ; 4 : Netral ; 5 : Agak Setuju ; 6 : Setuju ; 7 : Sangat Setuju).

Pada penelitian ini, peneliti menggunakan data demografis yaitu usia, jenis kelamin, status hubungan percintaan, orang tua, kepemilikan saudara, status tempat tinggal, angkatan kuliah, dan perkembangan skripsi. Selain data demografis, digunakan pula data sekunder terkait kesepian, yaitu durasi kesepian, penyebab kesepian, solusi atau kegiatan yang dilakukan saat kesepian, dampak saat merasakan kesepian dan data sekunder terkait skripsi, yaitu durasi pengerjaan skripsi, fasilitas sebelum mengambil mata kuliah skripsi, dan jadwal khusus seminar dan/atau siding skripsi.

Peneliti melakukan uji normalitas terlebih dahulu untuk menentukan uji parametrik atau nonparametrik. Data penelitian tidak berdistribusi normal, sehingga peneliti menggunakan uji beda non-parametrik yaitu uji Mann-Whitney dan uji Kruskall Wallis dengan aplikasi IBM Statistic SPSS $24^{\text {th }}$ edition.

\section{HASIL DAN PEMBAHASAN}

Tabel 1. Persebaran Data Demografis

\begin{tabular}{ccc}
\hline $\begin{array}{c}\text { Data } \\
\text { Demografis }\end{array}$ & Kategori & N \\
& 20 & 2 \\
Usia & 21 & 30 \\
& 22 & 169 \\
& 23 & 80 \\
Jenis & 24 & 41 \\
Kelamin & 25 & 8 \\
\hline \multirow{4}{*}{ Angkatan } & Laki-laki & 171 \\
& Perempuan & 159 \\
\hline Status & 2013 & 47 \\
Hubungan & 2014 & 46 \\
Percintaan & 2015 & 237 \\
\hline & Belum memiliki pasangan & 214 \\
& Berpacaran & 111 \\
Progress & Sudah Menikah & 5 \\
Skripsi & Menyusun BAB I - BAB III & 108 \\
& Sudah Seminar Usulan Penelitian & 39 \\
& Sedang mengambil data/olahdata/ & 136 \\
\hline
\end{tabular}


Tabel 1 memperlihatkan persebaran data demografis penelitian dengan keseluruhan sampel yakni 330 mahasiswa sarjana universitas padjadjaran yang hanya mengambil mata kuliah skripsi tanpa mengambil mata kuliah lain. Pada data demografis usia, partisipan mayoritas berusia 22 tahun. Data demografis jenis kelamin didominasi oleh jenis kelamin laki-laki. Pada data demografis angkatan mayoritas merupakan angkatan 2015. Pada status hubungan percintaan, mayoritas belum memiliki pasangan, sedangkan pada progres pengerjaan skripsi mayoritas mahasiswa sedang melakukan pengambilan data/olahdata/analisis data.

Tabel 2. Tingkat Kesepian Mahasiswa

\begin{tabular}{|c|c|c|c|c|c|c|}
\hline \multirow[b]{2}{*}{ Tingkat kesepian } & \multicolumn{2}{|c|}{ Kesepian } & \multicolumn{2}{|c|}{ Kesepian Sosial } & \multicolumn{2}{|c|}{ Kesepian Emosional } \\
\hline & $n$ & $\begin{array}{c}M \\
(S D)\end{array}$ & $n$ & $\begin{array}{c}M \\
(S D)\end{array}$ & $n$ & $\begin{array}{c}M \\
(S D)\end{array}$ \\
\hline Rendah & 272 & $\begin{array}{l}3.06 \\
(.54)\end{array}$ & 271 & $\begin{array}{c}3.02 \\
(1.03)\end{array}$ & 233 & $\begin{array}{c}3.05 \\
(0.58)\end{array}$ \\
\hline Netral & 2 & $\begin{array}{l}4.00 \\
(.00)\end{array}$ & 4 & $\begin{array}{l}3.30 \\
(.49)\end{array}$ & 7 & $\begin{array}{l}4.00 \\
(.00)\end{array}$ \\
\hline Tinggi & 56 & $\begin{array}{l}4.67 \\
(.52)\end{array}$ & 55 & $\begin{array}{c}3.10 \\
(1.12)\end{array}$ & 90 & $\begin{array}{l}4.75 \\
(.59)\end{array}$ \\
\hline
\end{tabular}

Tabel 2 memperlihatkan persebaran tingkat kesepian secara keseluruhan yaitu kesepian yang disebabkan oleh hubungan sosial dan hubungan emosional, persebaran tingkat kesepian berdasarkan jenis kesepian yaitu kesepian sosial dan kesepian emosional dari mahasiswa yang hanya mengambil mata kuliah skripsi. Sebagaimana yang telah terlihat pada Tabel 2, pada kesepian secara keseluruhan maupun kesepian berdasarkan dimensinya (kesepian sosial dan kesepian emosional), mayoritas mahasiswa merasakan tingkat kesepian yang rendah.

Peneliti juga menanyakan hal-hal yang membuat mahasiswa yang hanya mengambil mata kuliah skripsi merasakan kesepian berdasarkan teori kesepian yang telah dipaparkan oleh Perlman dan Peplau (1981) dan solusi yang dilakukan mahasiswa yang hanya mengambil matakuliah skripsi ketika merasakan kesepian sebagai data pendukung penelitian.

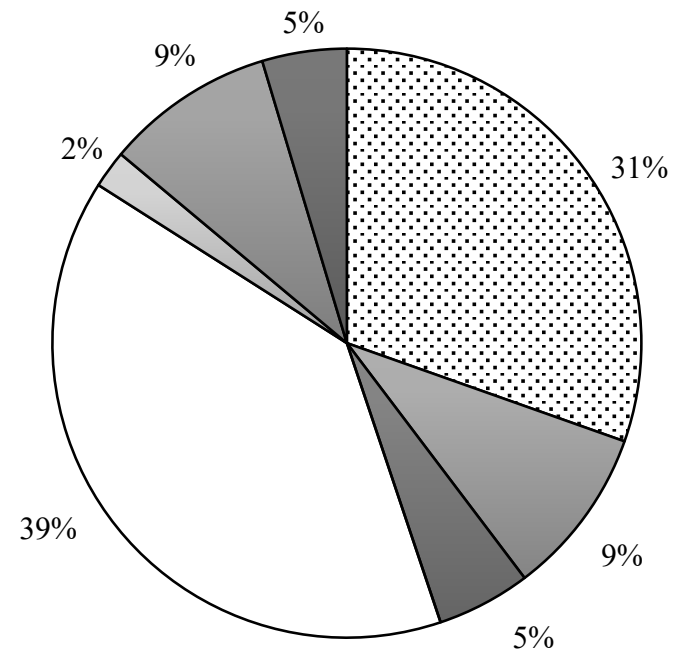

Grafik 1. Faktor Predisposing Kesepian
๑Menurunnya Kualitas dan Kuantitas Hubungan Pertemanan $\square$ Menurunnya Kualitas dan Kuantitas Hubungan Keluarga $\square$ Menurunnya Kualitas dan Kuantitas Hubungan Percintaan $\square$ Saat Sendirian

$\square$ Tidak Kesepian $\square$ Tidak mengetahui

口Tidak dapat menceritakan 
Grafik 1 memperlihatkan faktor predisposing yang menyebabkan mahasiswa merasakan kesepian. Faktor predisposing merupakan faktor yang membuat individu mudah merasakan kesepian, seperti faktor kepribadian, demografis, kemampuan dalam berhubungan sosial (kemampuan dan media dalam berkomunikasi dan berinteraksi), serta kesamaan individu dengan lingkungan sosialnya. Pada faktor predisposing, mayoritas mahasiswa memberikan respon lebih dari satu faktor yang membuat mereka merasakan kesepian, namun respon terbanyak adalah 39\% dari respons keseluruhan yaitu, mereka merasakan kesepian ketika sedang sendirian. Peringkat dari respon terbanyak adalah mengalami penurunan dalam kualitas pertemanan $31 \%$, banyak responden yang berpendapat karena banyak teman-teman yang telah lulus lebih dulu dari mereka, mereka jadi lebih jarang bertemu dari biasanya, sehingga menurunkan intensitas untuk berinteraksi dan jarang menghubungi lewat sosial media. Pada hubungan emosional yaitu hubungan keluarga, mahasiswa yang hanya mengambil mata kuliah skirpsi adalah mahasiswa perantauan, sehingga jarang bertemu dan berinteraksi dengan orang tuanya. Pada hubungan percintaan, pada mahasiswa yang memiliki pasangan menjalani hubungan jarak jauh, mereka jarang berinteraksi secara langsung dengan pasangan.

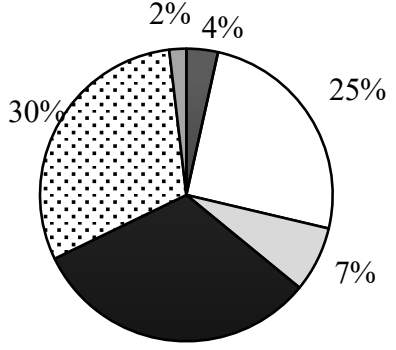

$32 \%$
口Memutuskan Hubungan Emosional $\square$ Berpisah secara fisik

$\square$ Perubahan Status

$\square$ Situasi kesepian

$\square$ Perubahan ekspektasi

口Tidak Kesepian

\section{Grafik 2. Faktor Precipitate Event}

Pada Grafik 2 memperlihatkan faktor precipitate event yaitu kondisi atau situasi yang dianggap dapat memicu meningkatnya rasa kesepian, serta membuat adanya ketidaksesuaian antara keinginan dan kebutuhan dalam hubungan sosial dengan hubungan sosial yang dimiliki saat ini (misalnya: putus dari kekasih, menyebabkan kebutuhan hubungan percintaan yang dulunya terpenuhi, jadi tidak terpenuhi kembali). Pada mahasiswa yang hanya mengambil mata kuliah skripsi, mayoritas diantara mereka (32\%) beranggapan bahwa situasi kesepian merupakan hal yang membuat mereka kesepian, yaitu kondisi dimana ketika setelah berada di tempat ramai atau setelah berinteraksi dengan orang yang dikenal, ketika kembali ke kos mereka mulai sendirian, sehingga merasakan kesepian. Adapun perubahan ekspektasi dalam hubungan sosial menjadi peringkat kedua terbanyak dari faktor precipitate event pada mahasiswa yang hanya mengambil matakuliah skripsi yaitu mereka beranggapan meskipun mereka belum lulus teman-teman yang telah lulus dan keluarga akan tetap mendukung mereka, namun ternyata pada kenyataannya berbeda dari yang diharapkan. 


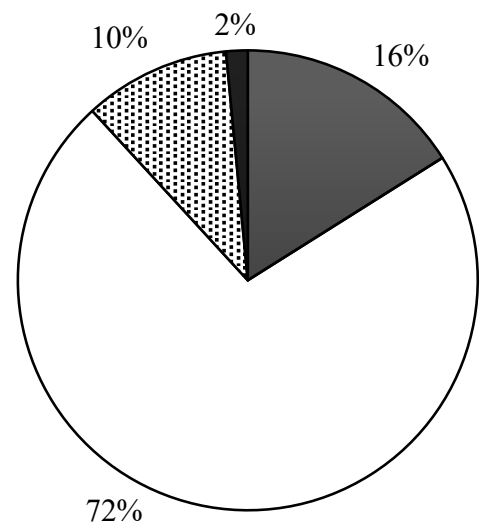

\author{
$\square$ Beradaptasi \\ $\square$ Memilih kegiatan yang dapat dinikmati \\ sendirian \\ 田Menerima kesepian \\ Tidak mengalami kesepian
}

\title{
Grafik 3. Solusi Ketika Kesepian
}

Grafik 3 memperlihatkan hal yang dilakukan mahasiswa untuk menanggulangi rasa kesepian mereka. Mayoritas mahasiswa memilih kegiatan yang dapat dinikmati sendirian untuk menanggulangi rasa kesepiannya, kegiatan yang dilakukan antara lain yaitu melakukan kegiatan yang menyenangkan seperti menonton film, beristirahat dan adapula yang menekuni hobi. Adapun mahasiswa yang memilih untuk beradaptasi dengan kesepiannya yaitu sebanyak 16\% dengan lebih memilih kegiatan yang dapat dinikmati sendirian. Beradaptasi yang dimaksudkan adalah ketika mereka merasa kesepian, mereka menghubungi orang lain lewat media sosial, mencoba untuk mencari kenalan baru, serta tidak berekspektasi terlalu tinggi terhadap hubungan sosialnya saat ini. Pada mahasiswa yang menerima kesepiannya, yaitu $10 \%$ mereka cenderung menangis, marah dan memunculkan emosi negatif saat mengalami kesepian, namun setelah mengeluarkan emosi negatif tersebut mereka sudah merasa kesepiannya berkurang dari sebelumnya.

Peneliti juga melihat jenis kesepian apa yang dirasakan lebih dominan oleh mahasiswa yang hanya mengambil mata kuliah skripsi yang akan dipaparkan pada grafik berikut:

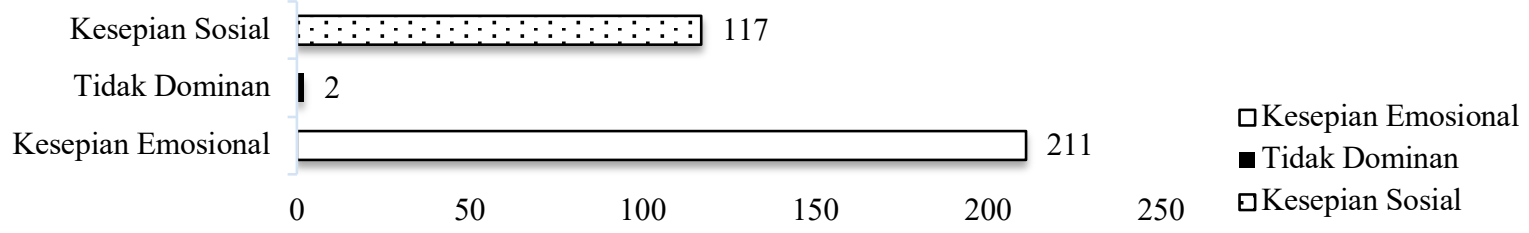

Grafik 4. Jenis Kesepian Dominan

Grafik 4 memperlihatkan dari 330 mahasiswa yang hanya mengambil mata kuliah skripsi, 211 mahasiswa merasakan kesepian sosial lebih dominan daripada kesepian emosional. Adapun 117 mahasiswa lainnya merasakan kesepian emosional lebih dominan dirasakan daripada kesepian sosial, sedangkan dua mahasiswa lainnya tidak merasakan adanya jenis kesepian apa yang lebih dominan dirasakan. 
Tabel 2 memperlihatkan tingkat kesepian mahasiswa yang hanya mengambil mata kuliah skripsi tanpa mengambil mata kuliah lain (mata kuliah mengulang atau pilihan). Sebanyak 272 mahasiswa yang hanya mengambil mata kuliah skripsi memiliki tingkat kesepian yang rendah. Berdasarkan teori Weiss (1947) hal ini terjadi karena mahasiswa telah merasa bahwa kebutuhan dalam hubungan sosial, yaitu kebutuhan akan social integration (kebutuhan untuk bertukar informasi dan pengalaman dengan orang lain) serta kebutuhan emosional, yaitu guidance (rasa percaya dan sosok yang dapat diandalkan dalam hubungan keluarga) dan attachment (kebutuhan akan kasih sayang atau kedekatan) sudah terpenuhi. Berdasarkan pernyataan dari alat ukur SELSA, mahasiswa yang memiliki tingkat kesepian yang rendah merasa bahwa dirinya sudah memiliki sekelompok teman untuk berbagi pandangan dan informasi, merasa bahwa dirinya adalah bagian dari keluarga dan telah memiliki seseorang yang memenuhi kebutuhan akan kehangatan dan kedekatan. Menurut Qualter (2015), seseorang yang memiliki tingkat kesepian yang rendah memperlihatkan bahwa sudah tercapainya intimacy atau kedekatan pada hubungan pertemanan, keluarga, maupun percintaan dan hal tersebut disebabkan oleh hubungan yang positif, yaitu adanya kedekatan yang sangat erat dan rendahnya konflik pada hubungan sosial yang sedang dijalani saat ini.

Tabel 2 juga memperlihatkan tingkat kesepian berdasarkan jenis kesepian. Pada kesepian sosial, 271 mahasiswa yang hanya mengambil mata kuliah skripsi merasakan tingkat kesepian sosial yang rendah dan menurut teori Weiss (1947), mereka telah merasa bahwa kebutuhan komponen social integration dilingkungan mereka saat ini masih dapat terpenuhi. Berdasarkan data yang didapat dari pernyataan alat ukur SELSA, mereka sudah merasa bahwa dirinya menyukai teman-temannya, memiliki sekelompok teman dan memiliki teman untuk berbagi cerita mengenai masalah yang dialaminya. Pada kesepian emosional, sebanyak 233 mahasiswa yang hanya mengambil mata kuliah skripsi merasakan tingkat kesepian emosional yang rendah. Menurut Weiss (1947) hal ini terjadi karena kebutuhan komponen guidance dalam hubungan keluarga kebutuhan attachment dalam hubungan percintaan sudah terpenuhi, meskipun pada Tabel 1 memperlihatkan bahwa mahasiswa yang hanya mengambil mata kuliah skripsi belum memiliki pasangan. Menurut Oulette (2004) hal ini dapat disebabkan oleh hubungan persahabatan yang dapat memenuhi kebutuhan akan kasih sayang atau kedekatan dari hubungan percintaan. Oleh karena itu, meskipun mayoritas mahasiswa belum memiliki pasangan, mereka mendapatkan kebutuhan attachment dari sosok sahabat. Berdasarkan item SELSA, mahasiswa yang memiliki tingkat kesepian emosional yang rendah sudah merasa bahwa dirinya dan keluarga memiliki rasa saling peduli satu sama lain dan mereka merasa bahwa telah memiliki seseorang yang memenuhi kebutuhan akan kehangatan dan seseorang yang mau berbagi dengan dirinya.

Adapun pada Tabel 2 memperlihatkan mahasiswa yang memiliki tingkat kesepian secara keseluruhan maupun berdasarkan jenis kesepian berada pada tingkat netral. Hal ini dapat diartikan bahwa mahasiswa yang hanya mengambil mata kuliah skripsi belum pernah merasakan atau mengalami pernyataan-pernyataan dalam alat ukur SELSA. Pada Tabel 2 juga memperlihatkan, 56 mahasiswa memiliki tingkat kesepian yang tinggi menurut teori Weiss (1947) hal ini terjadi karena mahasiswa merasa bahwa kebutuhan akan social integration (kebutuhan untuk bertukar informasi dan pengalaman dengan orang lain) dan kebutuhan emosional, yaitu guidance (rasa percaya dan sosok yang dapat diandalkan dalam hubungan keluarga) dan attachment (kebutuhan akan kasih sayang atau kedekatan) belum atau tidak terpenuhi. Berdasarkan pernyataan dari alat ukur SELSA, mahasiswa dengan tingkat kesepian yang tinggi cenderung merasa bahwa dirinya masih mengharapkan teman yang dapat memahami dan berbagi informasi dengan dirinya, mengharapkan agar keluarganya dapat memperhatikan kesejahteraan dirinya, tidak merasa dekat dengan keluarga, serta mengharapkan seseorang untuk mencintai dirinya dan dapat mengungkapkan rasa sayang pada seseorang yang dicintai. Menurut Qualter (2015), seseorang yang memiliki tingkat kesepian yang tinggi memperlihatkan bahwa belum tercapainya intimacy atau kedekatan pada hubungan pertemanan, keluarga, maupun percintaan dan hal tersebut disebabkan oleh hubungan yang negatif, yaitu banyaknya konflik pada hubungan sosial yang sedang dijalani saat ini.

Pada masing-masing kesepian yang diperlihatkan di Tabel 2. Pada mahasiswa dengan tingkat kesepian sosial yang tinggi, menurut Weiss (1974), hal ini terjadi karena kebutuhan social integration belum terpenuhi. 
Berdasarkan pernyataan dari alat ukur SELSA, mereka beranggapan bahwa mereka belum memiliki teman yang dapat memahami dan berbagi informasi atau pengalaman dengan dirinya. Menurut Fruman dan Buhrmester (1992), hal ini disebabkan oleh hubungan pertemanan yang negatif yaitu adanya konflik, serta tidak mendapat dukungan dan tidak adanya kedekatan emosional dalam hubungan pertemanan. Mahasiswa dengan tingkat kesepian emosional yang tinggi, menurut Weiss (1974), hal ini disebabkan oleh kebutuhan akan guidance dan attachment belum terpenuhi dalam hubungan emosional. Mahasiswa dengan tingkat kesepian emosional yang tinggi cenderung beranggapan bahwa tidak adanya kedekatan dalam hubungan keluarga, keluarga tidak memberikan dorongan terhadap dirinya, belum memiliki pasangan yang dapat berbagi perasaan, dukungan yang dibutuhkan dan masih mengharapkan seseorang untuk mencintai dirinya. Menurut Oulette (2004), hal ini dapat disebabkan oleh hubungan persahabatan yang belum memenuhi kebutuhan akan kasih sayang atau kedekatan dari hubungan percintaan.

Pada mahasiswa yang hanya mengambil mata kuliah skripsi cenderung mengalami kesepian akibat sendirian. Hal ini diperlihatkan pada Grafik 1 sebanyak 39\% dan Grafik 2 sebanyak 32\% yaitu faktor penyebab kesepian pada mahasiswa adalah ketika sendirian dan jika dilihat pada Grafik 3 yang menerangkan solusi yang dilakukan mahasiswa ketika kesepian yaitu 72\% mahasiswa memilih kegiatan yang dapat dinikmati sendirian. Pada Grafik 1 dan 2 juga memperlihatkan adanya faktor-faktor lain yang menyebabkan mahasiswa merasakan kesepian, seperti menurunnya kualitas dan kuantitas dalam hubungan pertemanan (31\%), keluarga (9\%) dan percintaan (5\%), adanya perubahan ekspektasi (30\%) dan berpisah secara fisik $(25 \%)$ dan beberapa mahasiswa cenderung memilih untuk beradaptasi dengan kesepian yang mereka alami (16\%). Adanya kesesuaian antara penyebab kesepian dan solusi yang dilakukan dapat menjadi salah satu faktor mayoritas mahasiswa yang hanya mengambil mata kuliah skripsi mengalami tingkat kesepian yang rendah dan apabila belum sesuai, misalkan mahasiswa memiliki penurunan kualitas dan kuantitas pertemanan. Namun jika memilih untuk melakukan kegiatan sendirian, hal ini di sisi lain dapat memicu meningkatnya rasa kesepian.

\section{SIMPULAN}

Mayoritas mahasiswa Universitas Padjadjaran yang hanya mengambil mata kuliah skripsi memiliki tingkat kesepian yang rendah, baik kesepian secara keseluruhan, maupun dilihat oleh dimensi-dimensi kesepian (kesepian sosial dan kesepian emosional). Hal ini dapat disebabkan oleh kebutuhan dalam hubungan sosial dan hubungan emosional telah terpenuhi. Adapun mereka dapat menyesuaikan penyebab kesepian dengan solusi yang dilakukan untuk menghadapi kesepian tersebut, yaitu mayoritas mahasiswa yang hanya mengambil mata kuliah skripsi merasakan kesepian ketika dirinya sedang sendirian dan mereka menanggulanginya dengan aktivitas yang dapat dinikmati sendirian, sehingga merasakan tingkat kesepian yang rendah.

\section{DAFTAR PUSTAKA}

Arnett J.J. (2014). A Longer Road to Adulthood. Emerging Adulthood. (Eds.2), 8-17. New York : Oxford University Press

Canham, Sarah L. Mauro, Pia M. Kaufmann, Christoper N. (2015). Association of Alchohol Use and Loneliness Frequency Among Middle-Aged and Older Adult Drinkers. J Aging Health, 267284.doi : https://doi.org/10.1177/0898264315589579

Camirand, Elisabeth. Poulin, Francouis. (2019). Changes in bestfriendship quality between adolescencce and emerging adulthood : Considering the role of romantic involvement. International Journal of Behavioral Development.doi : https://doi.org/10.1177/0165025418824995

Cavanaugh, Alyson M. Buehler, Cheryl. (2015). Adolescent loneliness and social anxiety: The role of multiple sources of support. Journal of Social and Personal Relationship 1-21.doi: https://doi.org/10.1177/0265407514567837

Chang, Edward C. Wan, Liangqiu. Li, Pengzi.dkk. (2017). Loneliness and Suicidal Risk in Young Adults: Does Believing in a Changeable Future Help Minimize Suicidal Risk Among the Lonely?. The Journal of Psychology, 1-11. doi : https://doi.org/10.1080/00223980.2017.1314928 
Christensen, Larry B. Johnson R. Burke. Turner, Lisa A. (2014). Measurement Techniques and Sampling Methods. Dalam Research Methods, Design, and Analysis. (Eds. 12)., 151-177. Boston : Pearson.

Di Tomasso, Enrico. Spinner, Barry. (1992). The The Development And Initial Validation Of Social And Emotional Loneliness Scale For Adults (Selsa). Pergamon Press, 127-134. doi : https://doi.org/10.1016/0191-8869(93)90182-3

Diehl, Katharina. Jansen, Charlotte.dkk. (2018). Loneliness at Universities: Determinants of Emotional and Social Loneliness among Students. International Journal of Environmental Research and Public Health. doi : https://doi.org/10.3390/ijerph15091865

Duck, R.Gilmour. (1981). Toward A Social Psychology Psychology of Loneliness. Dalam Personal Relationships in Disorder. London : Academic Press.

Hasan, M. Iqbal. (2001). Distribusi Sampling. Pokok-Pokok Materi Statistik 2 (Statistik Infrensif). Eds.2, hal. 89. Jakarta : Bumi Aksara.

Lee, Chih-Yuan S. Goldstein, Sara E. (2015). Loneliness, Stress, and Social Support in Young Adulthood : Does the Souce of Support Matter?. Springer Science+Bussiness Media. doi : https://doi.org/10.1007/s10964-015-0395-9

Muhammadin, M. P. (2015). Hubungan antara dimensi-dimensi loneliness dan penggunaan social network sites pada dewasa muda. Skripsi. Program Sarjana Universitas Indonesia Jakarta.

Narchal, Renu.A medavitt, Steven. (2017). Loneliness and Anxiety Sensitivity : Understanding Behavioral Avoidance in The Lonely. Act Psychopathological, 1-8. doi : https://doi.org /10.4172/2469-6676.10 0130

Peplau, L. A. Goldston S. (1984). Loneliness Research : A Survey of Empirical Findings. Preventing the Harmful Consequences of Severe and Presistent Loneliness. (Eds.1), 13-46. US : Goverment Printing Office

Pervin, M. Ferdowshi N. (2016). Suicidal Ideation In Relation To Depression, Loneliness And Hopelessness Among University Students (57-64). doi : https://doi.org/10.3329/dujbs.v25i1.28495

Qualter, Pamela. Vanhalst, Janne. Harris, Rebecca.dkk. (2015). Loneliness Across the Life Span. Perspectives on Psychological Science, 250-264. doi : https://doi.org/10.1177/1745691615568999

Santrock, J.W. (2018). Socioemotional Development in Late Adulthood. Life Span Development.(Eds. 17) 579580. New York : Mc Graw Hill.

Stoliker, Bryce E. Lafreniere, Kathryn, D. (2015). The Influence Of Perceived Stress, Loneliness , And Learning Burnout On University Students ' Educational Experience. College Student Journal, 146-160.

Weiten, Wayne. Dunn, Dana S. Hammer, Elizabeth Y. (2015). Friendship And Love. Psychology Applied to Modern Life Adjustment in the 21st Century, (Eds. 11) 285-289. USA : Cengage Learning. 